\title{
Occurrence of abnormal starfish Astropecten indicus (Doderlein, 1888) (Echinodermata: Astroidea) along Southeast coast of India
}

\author{
K. Prabhu \\ S. Bragadeeswaran * \\ Centre of Advanced Study in Marine Biology, Faculty of Marine Sciences \\ Annamalai University, Parangipettai - 608 502, Tamil Nadu, India \\ * Corresponding author \\ drpragaathi@gmail.com
}

Submetido em 29/02/2012

Aceito para publicação em 09/10/2012

\section{Resumo}

Ocorrência de anormalidade na estrela-do-mar Astropecten indicus (Doderlein, 1888) (Echinodermata: Astroidea) em águas costeiras de Parangipettai, costa sudeste da Índia. Exemplares de Astropecten indicus foram coletados acidentalmente em desembarques de pesca, no porto de Mudasalodai, Tamil Nadu em novembro de 2011. De um total de 134 indivíduos coletados, 3 (2,2\%) apresentavam um número anormal de braços (quatro ou seis). Normalmente, $A$. indicus tem cinco braços, sendo o desvio do pentamerismo um fenômeno raro em estrelas do mar. As observações sugerem que tais desvios não são hereditários, mas uma consequência das perturbações ambientais sobre a metamorfose de larvas e/ou regeneração anormal de braços.

Palavras-chave: Estrela-do-mar; Pentamerismo; Regeneração anormal

\section{Abstract}

Starfish Astropecten indicus was collected from bycatch landings at Mudasalodai fishing harbour, Tamil $\mathrm{Nadu}$ (India) in November 2011. Totally 134 specimens collected among three specimens $(2,2 \%)$ have abnormally developed four and six arms. Normally, A. indicus has five arms and the deviation from pentamerism is a rare phenomenon in starfishes. The present observations suggest that deviations from pentamerism are not a heritable character but are a consequence of environmental perturbations on the metamorphosis of larvae and/or abnormal regeneration of arms.

Key words: Abnormal regeneration; Pentamerism; Starfish 


\section{Introduction}

Echinoderms are pentamerous and therefore most of the asteroids have only five arms. However, some of the asteroids like Luidia maculata, Acanthaster planci and others always have more than five arms. In some of the asteroids like Pentaceraster regulus and Protoreaster linckii, the number of arms may be less than five or more than five due to freak formation at the time of development. Body shape abnormalities (e.g. abnormal arm number in normally pentamerous species) were also reported in asteroids. According to Hotchkiss (1979), these abnormalities appear to be generally the consequence of regeneration of predator injury.

In members belonging to the families Ophidiasteridae, Echinasteridae and some others, the arms are long, slender and brittle. They break either due to injury or by autonomy, especially when they are disturbed. Such specimens regenerate more number of arms, even though a complete starfish can be developed from a single arm. Although Echinoderms are highly evolved among invertebrates, they show primitive characters like autotomy, regeneration, radial symmetry and asexual reproduction (JAMES, 1999).

\section{Material and Methods}

\section{Sample collection}

Abnormal starfishes collected from bycatch landing (trawler) at mudasalodai fishing harbour (L1), Southeast coast of India in November 2011 (Figure 1) was preserved in 5\% buffered formalin - seawater mixture. Specimens were identified as Astropecten indicus (Doderlein, 1888) using the monograph of shallow water Indo-West Pacific echinoderms (CLARK; ROWE, 1971).

\section{Taxonomic characters}

Astropecten indicus has closely packed small abactinal paxillae but were not in regular transverse series. Superomarginal plates were distinct, often with a small tubercle-like spinelet. Two pairs of actinal intermediate plates in each interradius. Inferomarginal plates with a single, pointed spine at the margin and pointed spinelets on the actinal surface. The middle series of which consists of longer spinelets.

FIGURE 1: Study area.

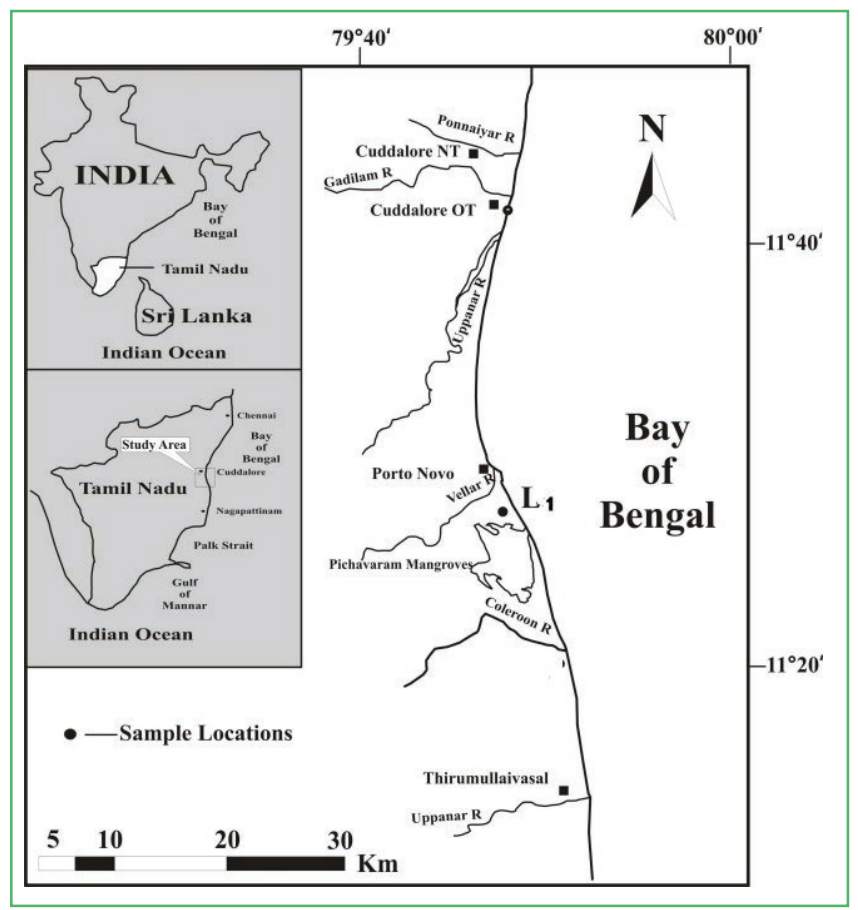

\section{Results and Discussion}

Astropecten indicus usually has five arms (Figure 2 ), but those with four arms (Figure 3) and six arms (Figure 4) were found in the present observation. The unusual or abnormal forms were exhibited due to either injury or by autonomy, especially when they are disturbed. Such specimens regenerate more number of arms. Worldwide, only limited observations were made on the abnormal forms of sea stars (HOTCHKISS, 2000). Although these forms were rare in global populations $(0.29 \%)$, they can reach important frequencies in some locations. James (1999) has reported six and four armed starfish $A$. indicus and some other abnormal seastars from Gulf of Mannar region (Table 1). Hotchkiss (2000) has reported the unusually wide and two ambulacural groove that extended in single tip. Samuel and Jerome (2002) have recorded four abnormal forms presenting deviation from the classical pentamerism of echinoderms observed within the brittle-star Amphipholis squamata. 
FIGURE 2: Astropecten indicus (usual forms).

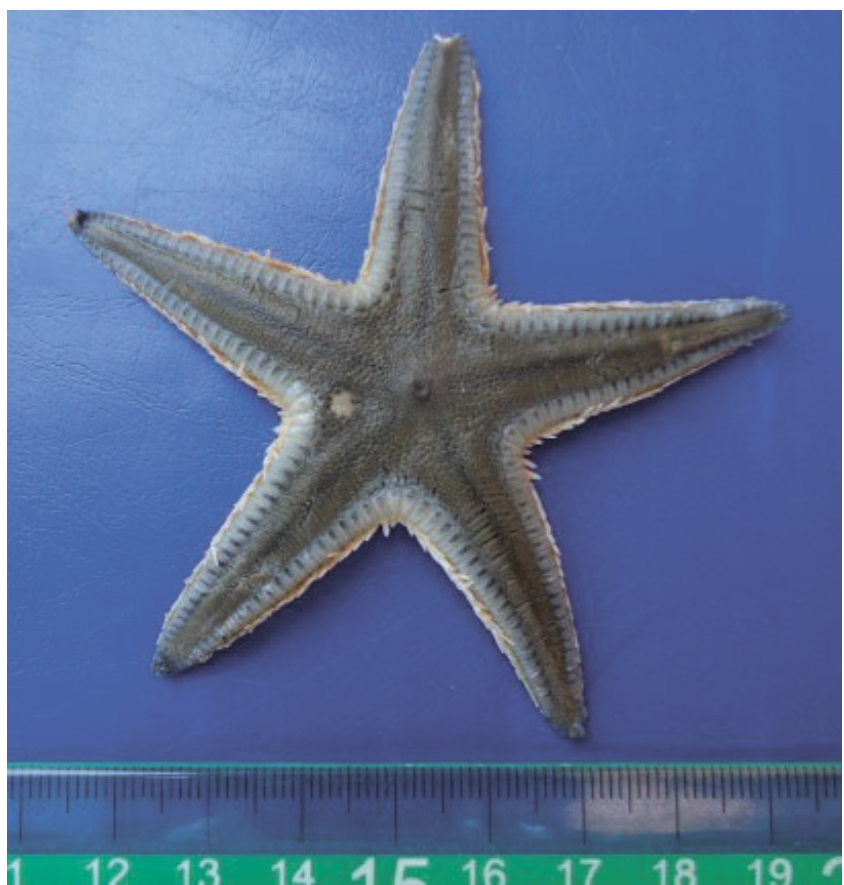

FIGURE 3: Astropecten indicus (abnormal 4 arms forms).

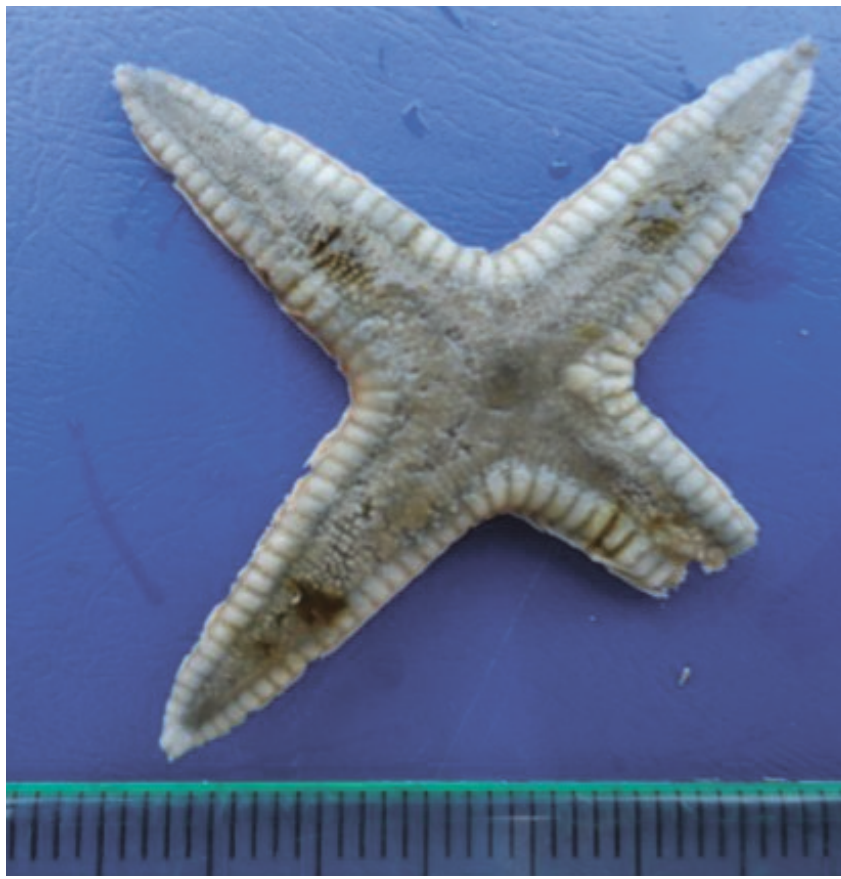

FIGURE 4: Astropecten indicus (abnormal 6 arms forms).
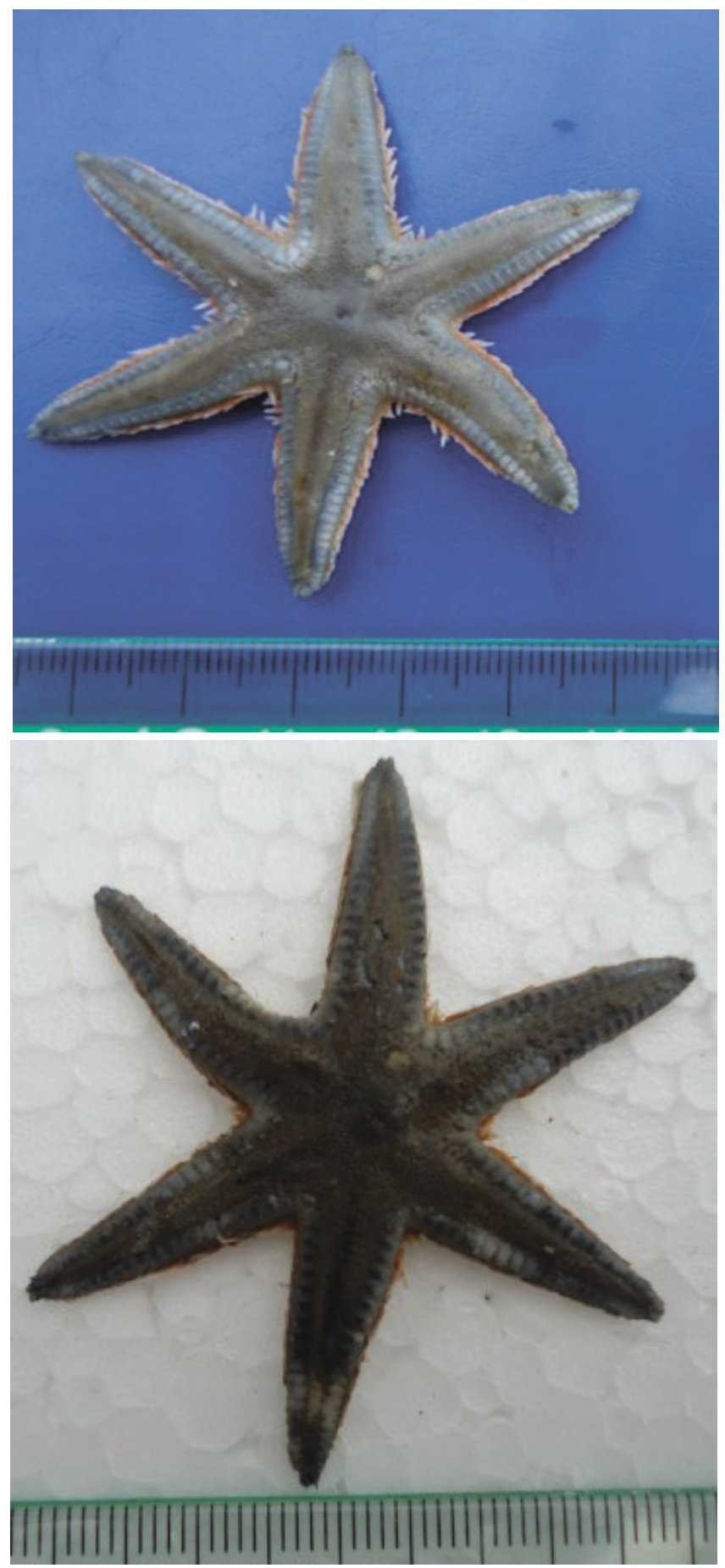
TABLE 1: Abnormal starfish species from Indian waters described by James (1999).

\begin{tabular}{llll}
\multicolumn{1}{c}{ Order } & \multicolumn{1}{c}{ Family } & \multicolumn{1}{c}{ Species } & \multicolumn{1}{c}{ Regions } \\
\hline Valvatida & Oreasteridae & Pentaceraster regulus & Gulf of Mannar \\
& & Protoreasler linckii & Mandapam \\
& Ophidiasteridae & Linckia multijora & Mandapam \\
& & Nardoa galatheae & Car Nicobar, Andaman \\
& Asterinidae & Asterina lorioli & Mandapam \\
Paxillosida & Astropectinidae & Astropecten indicus & Gulf of manner \\
\hline
\end{tabular}

Large number of strictly pentamerous families of starfish supports the interpretation of "rigid control" of pentamerism. As noted by Lawrence and Komatsu (1990) the control of ray number is very precise in fiverayed species. Four or three arms formed during the metamorphosis is the result of teratological incomplete development, which is generally consistent with the observations of Allain (1972) on Asterina gibbosa, Marsh et al. (1986) on Echinaster spinulosus and Clark (1988) on Patiria miniata. Watts et al. (1983) however present the evidence that ray number abnormalities in asteroids can be caused by high salinity during early development. The present results suggest that deviations from pentamerism are not a heritable character but are a consequence of environmental perturbations on the metamorphosis of larvae and/or abnormal regeneration of arms.

\section{Acknowledgement}

The authors grateful to the Dean, CAS in Marine Biology, Annamalai University for providing necessary facilities and encouragement and grateful University grant Commission, Govt. of India for providing research funding.

\section{References}

ALLAIN, J. Y. Une petite population d'Asterina gibbosa (Pennant) (Echinodermata, Asteroidea) tetramere, a` Dinard. Bulletin de la Société Scientifique de Bretagne, Rennes, v. 47, p.133-135, 1972. CLARK, A. M.; ROWE, F. W. E. Monograph of shallow water Indo-West pacific Echinoderms. Pub. No. 690. London: British Museum (Nat. His), 1971. 238 p.
CLARK, K. E. The roles of heredity, osmotic stress, and regeneration in non-pentamerous symmetry in Patiria miniata (Asteroidea). In: BURKE, R. D.; MLADENOV, P. V.; LAMBERT, P.; PARSLEY, R. L. (Ed.). Echinoderm Biology. Rotterdam: Balkema, 1988. 792 p.

JAMES, D. B. Abnormal asteroids from the seas around India. Marine Fisheries Information Service, Technical and Extension Series, 159, 1999. p. 21-22.

HOTCHKISS, F. H. C. Case studies in the teratology of starfish. Proceedings of the Academy of Natural Sciences of Philadelphia, Philadelphia, v. 131, p. 139-157, 1979

HOTCHKISS, F. H. C. Inferring the developmental basis of the sea star abnormality "double ambulacral groove" (Echinodermata: Asteroidea). Revista Chilena de Historia Natural, Santiago, v. 73, p. 579- 483, 2000.

SAMUEL, D.; JEROME, M. Abnormal forms in the brittle-star Amphipholis squamata: a field study. Journal of the Marine Biological Association of the United Kingdom, Cambridge, v. 82, p. 491-493, 2002.

LAWRENCE, J. M.; KOMATSU, M. Mode of arm development in multiradiate species of asteroids. In: DeRIDDER, C.; DUBOIS, P.; LAHAYE, M. C.; JANGOUX, M. (Eds). Echinoderm Research. Rotterdam: Balkema, 1990. p. 269-275.

MARSH, A. G.; WATTS, S. A.; CHEN, C. P.; MCCLINTOCK, J. B. The effect of high salinity on development, mortality and ray number of Echinaster spinulosus (Echinodermata: Asteroidea) at different developmental stages. Comparative Biochemistry and Physiology, Salt Lake City, v. 83A, p. 229-232, 1986.

WATTS, S. A.; SCHEIBLING, R. E.; MARSH, A. G.; McCLINTOCK. J. B. Induction of aberrant ray numbers in Echinaster sp., (Echinodermata: Asteroidea) by high salinity. Florida Scientist, Valdosta, v. 46, p. 120-125, 1983. 